\title{
The Policy of Cooperative and Small and Medium Enterprises Office in Improving Cooperative Achievement in Lampung Province
}

\author{
Fenny Andriani \\ fennyandriani1813@yahoo.com \\ Universitas Lampung, Indonesia \\ Eka Deviani \\ eka.deviani@fh.unila.ac.id \\ Universitas Lampung, Indonesia \\ Marlia Eka Putri AT \\ marlia_ekaputri@yahoo.co.id \\ Universitas Lampung, Indonesia
}

Submitted: 7 January 2021; Reviewed: 15 March 2021; Accepted: 30 April 2021

\begin{tabular}{|c|c|}
\hline Article's Information & Abstract \\
\hline $\begin{array}{l}\text { Keywords: } \quad \text { Policy; } \quad \text { Cooperative; } \\
\text { Improving; achievement }\end{array}$ & $\begin{array}{l}\text { Outstanding Cooperatives are cooperatives } \\
\text { that have achievements in obtaining their } \\
\text { performance in terms of organizational } \\
\text { aspects, management, management aspects, } \\
\text { productivity aspects, and benefit and impact } \\
\text { aspects of cooperatives that are stipulated by } \\
\text { the Decree of the State Minister for } \\
\text { Cooperatives and Small and Medium } \\
\text { Enterprises. The State Ministry for } \\
\text { Cooperatives and Small and Medium } \\
\text { Enterprises (Kementerian Koperasi dan Usaha } \\
\text { Kecil Menengah) has launched a cooperative } \\
\text { achievement assessment program to develop } \\
\text { and make existing cooperatives a success. The } \\
\text { prediction of cooperative achievements is } \\
\text { expected to motivate existing cooperatives to } \\
\text { function as economic institutions capable of } \\
\text { improving the welfare of members in particular } \\
\text { and society in general and building a national } \\
\text { economic order that creates a developed, just. }\end{array}$ \\
\hline
\end{tabular}


A prosperous society based on Pancasila and the 1945 Constitution. Building a national economic order creates a developed, just, and prosperous society based on Pancasila and the 1945 Constitution.

\section{A. Introduction}

National development is an effort to improve the quality of Indonesian people and society, carried out sustainably. ${ }^{1}$ One of the goals of national development, as stated in the Republic of Indonesia's constitution, is to promote public welfare, which means that the prosperity of the people takes precedence, not the prosperity of individuals. ${ }^{2}$ To advance the people's welfare, the government took the initiative to establish an institution called a cooperative. ${ }^{3}$ Cooperatives as the basis of the economy are manifested in the national economy's development aimed at realizing Indonesia's political and economic sovereignty. ${ }^{4}$ The cooperative was established to advance the welfare of members in particular and society in general to build a national economic order that creates a developed, just, and prosperous society based on Pancasila and the 1945 Constitution. ${ }^{5}$ Cooperatives and Small and Medium Enterprises (SMEs) or Koperasi dan Usaha Kecil dan Menengah (UKM) represent the people in the life of the national and regional economy, so that it needs to be given high priority in national and regional development. ${ }^{6}$ The development of cooperatives as business entities is the pillar of the national economy, which is intended as an aspiration for cooperatives' role in the future. ${ }^{7}$ A cooperative is a business entity that has an important meaning in the country's economy for its cooperative members' welfare. The government seeks to strengthen cooperative capital by providing capital assistance to develop cooperatives and SMEs.

In connection with the policies that need to be made by the Cooperatives and Small and Medium Enterprises Service, it is inseparable from their main duties and functions as regulated in the Lampung Provincial Regulation Number 13 of 2009 concerning the organization and work procedures of regional offices in article 26 states that the Cooperatives and SME Service the task of carrying out part of the provincial government affairs in the field of cooperatives based on the principle of autonomy which becomes the authority, deconcentration and assistance tasks as well as other tasks following the policies stipulated by the Governor based on the prevailing laws and regulations. ${ }^{8}$

\footnotetext{
1 Yuli Suci Rahmini, "PERKEMBANGAN UMKM (USAHA MIKRO KECIL DAN MENENGAH) DI INDONESIA," Cano Ekonomos 6, no. 1 (2017): 51-58, https://www.neliti.com/publications/58432/.

${ }^{2}$ Latif Adam, "Pelibatan Koperasi Dalam Program KUR: Sebuah Inovasi Kebijakan Ekonomi Dengan Peluang Dan Tantangannya," Jurnal Ekonomi Pembangunan 26, no. 1 (June 29, 2018): 21-46, https://doi.org/10.14203/jep.26.1.2018.2146.

${ }^{3}$ Muhammad Ridwan,. Hartutiningsih, and Massad Hatuwe, "PEMBINAAN INDUSTRI KECIL DAN MENENGAH PADA DINAS PERINDUSTRIAN, PERDAGANGAN, KOPERASI DAN UMKM KOTA BONTANG," Jurnal Administrative Reform (JAR) 2, no. 2 (July 13, 2017): 187-99, https://doi.org/10.30872/JAR.V2I2.510.

${ }^{4}$ Arief Budiyanto and Aidil Amin Effendy, "Analisa Kebijakan Pemerintah Kota Tangerang Selatan Terhadap Pemberdayaan Koperasi Dan UMKM Dan Dampaknya Terhadap Pemerataan Kesejahteraan Masyarakat," Jurnal Mandiri: Ilmu Pengetahuan, Seni, Dan Teknologi 4, no. 1 (June 22, 2020): 80-93, https://doi.org/10.33753/mandiri.v4i1.77.

${ }^{5}$ Hari Sutra Disemadi and Kholis Roisah, "KEBIJAKAN MODEL BISNIS BANK WAKAF MIKRO SEBAGAI SOLUSI PEMBERDAYAAN EKONOMI MASYARAKAT,” LAW REFORM 15, no. 2 (September 30, 2019): 177-94, https://doi.org/10.14710/lr.v15i2.26176.

6 Muhammad Syaiful, Hasan Aedy, and Irmawatty Paula Tamburaka, "STRATEGI KOPERASI DALAM MENINGKATKAN KESEJAHTERAAN ANGGOTA,” Jurnal Progres Ekonomi Pembangunan 1, no. 1 (2016), http://ojs.uho.ac.id/index.php/JPEP/article/view/874.

7 Adnan Husada Putra, "Peran UMKM Dalam Pembangunan Dan Kesejahteraan Masyarakat Kabupaten Blora," Artikel Jurnal Analisa Sosiologi Oktober, vol. 2016, February 12, 2018, https://doi.org/10.20961/JAS.V5I2.18162.

${ }^{8}$ Wahyu Dede Kusuma and Viki Anggraini Soeprapto, "EFEKTIVITAS PENGALIHAN DANA DEKONSENTRASI DAN TUGAS PEMBANTUAN KE DANA ALOKASI KHUSUS," Jurnal Anggaran Dan Keuangan Negara Indonesia (AKURASI) 2, no. 1 (June 29, 2018): 24, https://doi.org/10.33827/akurasi2018.vol2.iss1.art33.
} 
In terms of the cooperative development and empowerment program's success, the State Ministry for Cooperatives and Small and Medium Enterprises (Kemenkop and UKM) has launched a program, namely the cooperative achievement assessment program. Ministry Regulation No. 06/Per/M.KUKM/V/2006 Achieving Cooperative is a cooperative that has achievements in achieving its performance in terms of organizational aspects, management, and management aspects, productivity aspects, as well as aspects of benefits and impacts of cooperatives which are stipulated by the Decree of the State Minister for Cooperatives. and Small and Medium Enterprises. ${ }^{9}$ The cooperative achievement predicate is the highest award in the cooperative sector which is only awarded to the selected cooperative. ${ }^{10}$ In fact, in Lampung Province, there are still many cooperatives that are categorized as unhealthy or even inactive. A proper policy is needed to be made by the Cooperatives and Small and Medium Enterprises Service in motivating existing cooperatives to avoid the increasing number of underdeveloped cooperatives. ${ }^{11}$

Based on the above background, the main point of view that will be analyzed is the cooperative program's policy with achievement. The problems in this matter are as follows: What is the policy of the Cooperatives and Small and Medium Enterprises Office in building cooperative achievements? What are the challenges faced by the Cooperatives and Small and Medium Enterprises Office in building high-performing cooperatives? This study uses the statue approach. The statutory approach (statue approach) is used to map the basis for the Cooperatives and Small and Medium Enterprises (SMEs) Office's authority in the formation of effective policies to develop cooperatives in Lampung province. And data analysis is carried out in a prescriptive-analytical manner, namely examining legal concepts, legal principles, legal norms, and legal systems related to the development and fostering of cooperatives by the Cooperatives and SME Service. Thus, it will be seen if the Bandar Lampung City Cooperatives and SME Office have taken the right policies in the cooperative achievement program.

\section{B. Discussion}

\section{Supervision and the Role of the Cooperatives and SMEs Service in Building High- Performing Cooperatives}

An economy that continues to grow and develop is one of the goals of the Indonesian nation. ${ }^{12}$ There are many ways to make it happen, one of which is developing cooperatives and SMEs in Indonesia. To make this happen, the government, together with the Cooperatives and SMEs Offices in each region, work together to strengthen the empowerment of cooperatives and SMEs as strategic social-economic institutions to increase community groups' income. The Office of Cooperatives and MSEs in Lampung Province is an implementing element for implementing the regional government, which was formed based on the Regulation of the Governor of Lampung Number 13 of 2009 concerning the Organization and Administration of the Regional Office of Lampung Province. The Department of Cooperatives and Small and Medium Enterprises of Bandar Lampung City has a mission to increase economic growth (pro-growth) through developing the potential and advantages of Lampung province by strengthening investment (pro-investment) in various

\footnotetext{
${ }^{9}$ Laurensius Arliman S, "PERLINDUNGAN HUKUM UMKM DARI EKSPLOITASI EKONOMI DALAM RANGKA PENINGKATAN KESEJAHTERAAN MASYARAKAT," Jurnal Rechts Vinding: Media Pembinaan Hukum Nasional 6, no. 3 (December 18, 2017): 387, https://doi.org/10.33331/rechtsvinding.v6i3.194.

${ }^{10}$ https://www.republika.co.id/berita/ekonomi/keuangan/18/07/13/pbt6mp365-pemerintah-beri-penghargaan-koperasiberprestasi, accessed 17 September 2020.

${ }^{11}$ Marlinda Apriyani et al., "Income Level and Determinants of Revenue SMEs in Bandar Lampung," Jurnal Ilmiah Esai 10, no. 1 (2016): 71-77, https://jurnal.polinela.ac.id/index.php/ESAI/article/view/1354.

12 Dian Prihardini Wibawa and Maya Yusnita, "Menakar Peran Pemerintah Dan Akademisi Terhadap Pengembangan UMKM,” Jurnal Penelitian Ipteks, vol. 5, January 14, 2020, https://doi.org/10.32528/IPTEKS.V5I1.3020.
} 
sectors and a community-based economy with partnerships. This mission has a single objective with the objectives as well as a strategy and policy direction, which are formulated as follows:

Target:

The realization of high economic growth, a strong economic structure, and an increase and equal distribution of people's income.

Strategy:

Strengthening the empowerment of Cooperatives and MSMEs as strategic social-economic institutions to increase the income of low-income groups of people and open employment opportunities for local workers

Policy Direction:

1. Encouraging Institutional Strengthening and Increasing the competitiveness of MSMEs and Cooperatives so that they can grow into sustainable businesses on a larger scale

2. Improve facilities, technology, marketing, and capital to MSMEs and creative businesses.

The ideals and goals of the Indonesian people and the Office of Cooperatives and Small and Medium Enterprises of Lampung Province's mission are inversely proportional to the facts in the field. ${ }^{13}$ In 2020, Lampung Province had 2,087 active cooperative units, then 683 cooperatives have Cooperative Registration Number (NIK) certification, and 30 cooperatives are declared healthy. ${ }^{14}$ Based on these data, it can be seen that the number of cooperatives that are declared healthy is minimal when compared to the number of existing cooperatives.

Very few cooperatives have been declared outstanding in Lampung Province. In 2014 the Family and Employee Cooperative (Kopkar Kekar) PT. Pelabuhan Indonesia II (Persero) Cabang Panjang succeeded in making achievements by receiving an award from the Department of Cooperatives, SMEs, Industry, and Trade of Bandar Lampung City as Rank I Outstanding Cooperative in Bandar Lampung City for the category of Employee Cooperative Groups. ${ }^{15}$ In 2018 the Mekar Sai Kopdit Savings and Loans Cooperative (KSP) became one of the ten cooperatives that received an award from the Lampung Provincial Government as an outstanding cooperative ${ }^{16}$ In 2019, the Handayani Employee Cooperative of the Republic of Indonesia (KPRI) was named the Lampung Province Outstanding Cooperative. ${ }^{17}$ The indicators in determining the cooperative with achievement are that the cooperative can apply cooperatives' principles, the welfare of members, and is financially sound.

Based on the facts in the field above, the right policies are needed to increase the awareness of cooperatives in Lampung province in terms of self-improvement and welfare of their members. Also, to find out cooperatives' performance in a certain period and develop synergy for cooperative empowerment, and increase the participation of related agencies in the cooperative movement in society for cooperative development, which can describe the level of success of a cooperative. To discuss the Office of Cooperatives and SMEs' policies in

\footnotetext{
13 Chaerani Nisa, "Analisis Dampak Kebijakan Penyaluran Kredit Kepada Umkm Terhadap Pertumbuhan Pembiayaan Umkm Oleh Perbankan [Policy Impact Analysis of Lending to MSMEs on the Growth of MSMEs Financed by Banks]," DeReMa (Development Research of Management): Jurnal Manajemen 11, no. 2 (October 7, 2016): 212, https://doi.org/10.19166/derema.v11i2.231.

${ }^{14}$ https://altumnews.com/2020/12/31/pemberdayaan-koperasi-dan-umkm-di-provinsi-lampung-di-tengah-badai-covid-19/, accessed 11 March 2021

${ }^{15}$ https://www.panjangport.co.id/?bW9kPXBhZ2UvYmVyaXRhJnBnPWRldGFpbF9iZXJpdGEmZGV0YWlsPTU3JnJhbmR vbT01YlBqeThEQXQ= accessed 19 September 2020

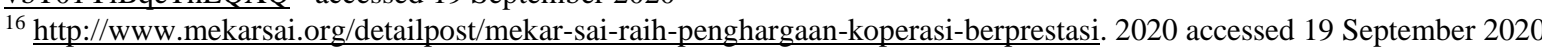

17 https://smartnews.id/kpri-handayani-dinobatkan-koperasi-berprestasi-tingkat-provinsi-lampung. accessed 19 September 2020
} 
Lampung Province, we will refer to the function of the Lampung Province Cooperatives and SME Service in terms of formulating policies. These policies are described as follows:

1. Cooperative Sector

a. Formulating an operational plan for the cooperative development program guided by the efforts towards a healthy and outstanding cooperative;

b. Establishment of technical policies for operational programs and budget for strengthening assistance in creating a conducive climate for cooperative growth;

c. Implementing guidance to improve the quality of cooperative supervisors and administrators in the fields of financing facilities, business development, institutional development, and data information programs as well as improving the quality of human resources;

d. Assisting in business strengthening and capital strengthening.

e. To protect cooperatives from unfair competition practices in the business sector.

2. Small and Medium Enterprises Sector

a. Preparation of operational plans for small and medium enterprise development programs;

b. Perform research and study of regional potential for the development of small and medium enterprises as well as create a database for small and medium enterprises in the area;

c. Perform coaching for small and medium enterprises;

d. Providing assistance and strengthening of business capital;

e. Control over the implementation of equity participation in small and medium enterprises.

Based on the function in terms of making policies and seen from the goals, strategies, and direction of the Lampung Province Cooperative and SMEs Service policies, a policy is made in the form of a cooperative achievement assessment program. This is one of the government's efforts to grow the economy by awarding outstanding cooperatives to cooperatives deemed to meet qualifications. The assessment of cooperative achievements is expected to encourage and motivate existing cooperatives to continue to develop and have competitiveness so that they can grow into sustainable businesses on a larger scale.

In addition to carrying out its function in making policies, the Office of Cooperatives and SMEs also carries out its role and duties to guide existing cooperatives to become healthy cooperatives and achieve the title of cooperative with achievement. ${ }^{18}$ The Cooperative and SMEs Service task is to provide guidance, namely to provide socialization and counseling on cooperatives to the community and the Cooperative movement that is not against the laws and regulations so that people understand, have knowledge and skills about the correct procedures for cooperating and SMEs. ${ }^{19}$ Besides, the Lampung Office of Cooperatives and SMEs also provide technical guidance, training for the managers and managers of cooperatives and SMEs to have quality and competitive advantages in developing cooperatives and their SMEs. Untuk hal ini Dinas Koperasi dan UKM Lampung bekerjasama dengan Dinas Cooperatives and UKM in each region in Lampung Province, conduct outreach, technical guidance and trainings. This is intended to lead to quality and rewarding cooperative.

The general strategy for coaching towards high-performing cooperatives carried out by the Cooperatives, and UKM Service is carried out at four levels:

\footnotetext{
18 Wido Prananing Tyas, Onixtin Octarina Sianturi, and Julius Kevin P H, “ANALISIS KEBIJAKAN PEMERINTAH DALAM PENGEMBANGAN USAHA MIKRO KECIL DAN MENENGAH (UMKM) BERBASIS RUMAH (HOMEBASED ENTERPRISES/HBE) DI KOTA SEMARANG, SURAKARTA, BOYOLALI, SALATIGA, DAN SURABAYA," Jurnal Pengembangan Kota 8, no. 1 (July 1, 2020): 78-89, https://doi.org/10.14710/jpk.8.1.78-89.

${ }^{19}$ Sri Maulida and Ahmad Yunani, "Peluang Dan Tantangan Pengembangan Usaha Mikro Kecil Menengah," Jurnal Ilmiah Manajemen Dan Bisnis 2, no. 1 (September 22, 2017): 181-97, http://journal.undiknas.ac.id/index.php/manajemen.
} 
1. The Awakening Strategy is intended for fostering cooperatives that do not perform well to become sufficiently high achievers. Efforts are made by disseminating existing official programs comprehensively and preparing the basic cooperative infrastructure.

2. The Empowering Strategy is intended to foster underachieving cooperatives to become moderately high achievers. Efforts are made by providing an understanding of the essence of cooperating and development efforts that need to be straightened out and emphasized, reviewing the roles of each stakeholder in formulating legal rules that can be used as a strong basis, program clarity, budget availability, supporting human resources and effective coordination between related agencies, compiling mentoring programs that are relevant to the progress of cooperatives, providing funds obtained from various sources and selecting local institutions that are must be transparent in meeting the needs of the problems at hand.

3. Strategy Developing (Developing) is intended to foster cooperatives with sufficient achievement to become high achievers. Efforts are made by providing an understanding of the essence of cooperating along with development efforts that need to be strengthened and enriched, so that existing institutions need to be increased in their roles and encouraged to be able to stimulate local policies related to people's economic problems, providing support for local assistance programs that are integrated with the national development program, providing matching funds from the Dinas so that it does not depend on the Center, and involving local potentials and institutions that need to be expanded.

4. The Strengthening Strategy is intended for fostering high-achieving cooperatives to become highly accomplished. Efforts are made by understanding the essence of cooperating along with development efforts that need to be uniformed and made a strong legal basis, a clear description of authority, and adequate supporting resources.

The four general strategies for fostering a cooperative with high achievement above must be included with a cooperative supervision system that is sustainable and optimal. In terms of supervision of cooperatives, it can be done internally and externally. The cooperatives' internal supervision is under the Cooperative Law Number 25 of 1992 with the provisions of article 38 and article 39.

Supervision is an assessment that is a process of measuring and verifying a series of processes that have been carried out on an ongoing basis. ${ }^{20}$ According to Sujamto, supervision is any effort or activity to assess the actual reality of the implementation of a task or activity, whether it is appropriate or not. According to Mc. Ferland ${ }^{21}$ Supervision is a process where the leader wants to know whether the results of the implementation of the work carried out by his subordinates are under the plan, sequence, objectives, or policies that have been determined. ${ }^{22}$ Conceptually, supervision consists of the function of supervision, internal supervision, community supervision, which is marked by the existence of regular courts and a system of supervision, coordination, integration, and synchronization of the supervisory apparatus, the establishment of a supervisory information system that supports follow-up implementation, as well as the number and quality of professional auditors who adequate, the intensity of follow-up supervision and law enforcement that is fair and consistent. ${ }^{23}$

External supervision of cooperatives is carried out by government officials who have been given the authority and boundaries, of course, carried out by the Cooperatives and UKM Service, both at the provincial and district levels. ${ }^{24}$ External supervision in general to

\footnotetext{
${ }^{20}$ Suriansyah Murhaini, 2014, Manajemen Pengawasan Pemerintahan Daerah, Pustaka Pelajar, Yogyakarta, pg. 4.

${ }^{21}$ Jum Anggriani, 2012, Hukum Administrasi Negara, Graha Ilmu, Yogyakarta, pg 78.

${ }^{22}$ Soewarno Handayaningrat, 1990, Pengantar Studi Ilmu Administrasi dan Managemen, CV Haji Masagung, Jakarta, pg.113

${ }^{23}$ Diana Halim Koencoro, 2004, Hukum Administrasi Negara, Ghalia Indonesia, Bogor, pg.74

${ }^{24}$ Kristina Sedyastuti, "Analisis Pemberdayaan UMKM Dan Peningkatan Daya Saing Dalam Kancah Pasar Global," INOBIS: Jurnal Inovasi Bisnis Dan Manajemen Indonesia 2, no. 1 (July 31, 2018): 117-27, https://doi.org/10.31842/jurnalinobis.v2i1.65.
} 
cooperatives has been regulated in the Cooperative Law number 25 of 1992, Chapter XII, articles 60, 61, 62, and 63 .

Also, the role of the Cooperative and UKM Service in building Outstanding Cooperatives in Lampung Province from the results of interviews conducted with KPRI Handayani officials, Mr. Muhammad Yusri, S.Pd., M.M. It was obtained a statement that the role of the Cooperatives and SMEs Office so far has been to carry out a pattern of regular and continuous guidance and supervision that has been arranged in the outstanding cooperative team from the Cooperatives and SMEs Service. From the findings of the cooperative team with achievements regarding the existing weaknesses or deficiencies, both from the management system, financial system, organizational system, and management in the cooperative being managed, the findings are immediately followed up to get a solution or solution that is correct under existing set procedures.

The Office of Cooperatives and SMEs' role in building outstanding cooperatives is to provide direction in obtaining capital strengthening by providing information on various sources of capital from both public and private institutions. For example, funds from the Ministry of Cooperatives through the Revolving Fund Capital Institution or Lembaga Permodalan Dana Bergulir (LPDB), banks, funds in the form of capital participation, or Anggaran Pendapatan dan Belanja Daerah (APBD)

In addition to providing guidance, supervision, and capital information, the Cooperatives and SMEs Service also prioritizes providing training, technical guidance, and socialization about cooperatives to cooperative managers to provide additional knowledge and skills in managing good cooperatives and achievers. Besides that, it also prioritizes the management to be included in comparative study programs in several places outside the province of Lampung, such as in the Java region. The goal is so that the management can see firsthand cooperatives that have succeeded to become cooperative with achievements.

\section{The challenges faced by the Cooperatives and SME Service Offices in building outstanding cooperatives}

The challenges faced by the Cooperatives and SME Service Offices in building outstanding cooperatives

1. Lack of Human Resources

Currently, the Bandar Lampung Cooperatives and SME Service only have 95 (ninetyfive) civil servants and 8 (eight) freelance daily employees. This is very inappropriate when compared to the number of cooperatives in Lampung Province.

2. Infrastructure Office of Cooperatives and SMEs that are still less supportive.

To accommodate and provide guidance to 2,087 cooperatives in Bandar Lampung, the facilities and infrastructure are still inadequate, especially the lack of official vehicles used in official activities.

\section{Conclusion}

The Office of Cooperatives and SMEs' role in building high-achieving cooperatives in Lampung Province has not been running optimally. This can be seen from the Bandar Lampung Cooperatives and UKM Service's ineffective coaching and supervision patterns so that there are still many active cooperatives that have not received regular and continuous guidance and supervision. The inhibiting factor of the Cooperatives and SME Service Offices in building outstanding cooperatives in Lampung Province is a lack of human resources compared to the number of cooperatives that exist today, namely 2,087 cooperatives. Another inhibiting factor faced by the Bandar Lampung Cooperatives and SMEs Service is the lack of facilities and infrastructure for mobilizing monitoring and evaluation in the form of official vehicles. 


\section{Bibiliography}

\section{A. Book}

Diana Halim Koencoro, 2004, Hukum Administrasi Negara, Bogor: Ghalia Indonesia. Jum Anggriani, 2012, Hukum Administrasi Negara, Yogyakarta: Graha Ilmu, Yogyakarta.

Soewarno Handayaningrat, 1990, Pengantar Studi Ilmu Administrasi dan Managemen, Jakarta: CV Haji Masagung.

Suriansyah Murhaini, 2014, Manajemen Pengawasan Pemerintahan Daerah, Yogyakar: Pustaka Pelajar,.

\section{B. Journal}

Adam, Latif. "Pelibatan Koperasi Dalam Program KUR: Sebuah Inovasi Kebijakan Ekonomi Dengan Peluang Dan Tantangannya.” Jurnal Ekonomi Pembangunan 26, no. 1 (June 29, 2018): 21-46. https://doi.org/10.14203/jep.26.1.2018.21-46.

Apriyani, Marlinda, Endang Asliana, Dan Fadila, and Marga Saty. "Income Level and Determinants of Revenue SMEs in Bandar Lampung." Jurnal Ilmiah Esai 10, no. 1 (2016): 71-77. https://jurnal.polinela.ac.id/index.php/ESAI/article/view/1354.

Arliman S, Laurensius. "PERLINDUNGAN HUKUM UMKM DARI EKSPLOITASI EKONOMI DALAM RANGKA PENINGKATAN KESEJAHTERAAN MASYARAKAT." Jurnal Rechts Vinding: Media Pembinaan Hukum Nasional 6, no. 3 (December 18, 2017): 387. https://doi.org/10.33331/rechtsvinding.v6i3.194.

Budiyanto, Arief, and Aidil Amin Effendy. "Analisa Kebijakan Pemerintah Kota Tangerang Selatan Terhadap Pemberdayaan Koperasi Dan UMKM Dan Dampaknya Terhadap Pemerataan Kesejahteraan Masyarakat.” Jurnal Mandiri : Ilmu Pengetahuan, Seni, Dan Teknologi 4, no. 1 (June 22, 2020): 80-93. https://doi.org/10.33753/mandiri.v4i1.77.

Kusuma, Wahyu Dede, and Viki Anggraini Soeprapto. "EFEKTIVITAS PENGALIHAN DANA DEKONSENTRASI DAN TUGAS PEMBANTUAN KE DANA ALOKASI KHUSUS.” Jurnal Anggaran Dan Keuangan Negara Indonesia (AKURASI) 2, no. 1 (June 29, 2018): 24. https://doi.org/10.33827/akurasi2018.vol2.iss1.art33.

Nisa, Chaerani. "Analisis Dampak Kebijakan Penyaluran Kredit Kepada Umkm Terhadap Pertumbuhan Pembiayaan Umkm Oleh Perbankan [Policy Impact Analysis of Lending to MSMEs on the Growth of MSMEs Financed by Banks]." DeReMa (Development Research of Management): Jurnal Manajemen 11, no. 2 (October 7, 2016): 212. https://doi.org/10.19166/derema.v11i2.231.

Putra, Adnan Husada. "Peran UMKM Dalam Pembangunan Dan Kesejahteraan Masyarakat Kabupaten Blora." Artikel Jurnal Analisa Sosiologi Oktober. Vol. 2016, February 12, 2018. https://doi.org/10.20961/JAS.V5I2.18162.

Rahmini, Yuli Suci. "PERKEMBANGAN UMKM (USAHA MIKRO KECIL DAN MENENGAH) DI INDONESIA." Cano Ekonomos 6, no. 1 (2017): 51-58. https://www.neliti.com/publications/58432/.

Ridwan, Muhammad, . Hartutiningsih, and Massad Hatuwe. "PEMBINAAN INDUSTRI KECIL DAN MENENGAH PADA DINAS PERINDUSTRIAN, PERDAGANGAN, KOPERASI DAN UMKM KOTA BONTANG." Jurnal Administrative Reform (JAR) 2, no. 2 (July 13, 2017): 18799. https://doi.org/10.30872/JAR.V2I2.510.

Sedyastuti, Kristina. "Analisis Pemberdayaan UMKM Dan Peningkatan Daya Saing Dalam Kancah Pasar Global." INOBIS: Jurnal Inovasi Bisnis Dan Manajemen Indonesia 2, no. 1 (July 31, 2018): 117-27. https://doi.org/10.31842/jurnal-inobis.v2i1.65.

Sri Maulida, and Ahmad Yunani. "Peluang Dan Tantangan Pengembangan Usaha Mikro Kecil Menengah.” Jurnal Ilmiah Manajemen Dan Bisnis 2, no. 1 (September 22, 2017): 181-97. http://journal.undiknas.ac.id/index.php/manajemen.

Sutra Disemadi, Hari, and Kholis Roisah. "KEBIJAKAN MODEL BISNIS BANK WAKAF MIKRO SEBAGAI SOLUSI PEMBERDAYAAN EKONOMI MASYARAKAT." LAW REFORM 15, 
no. 2 (September 30, 2019): 177-94. https://doi.org/10.14710/lr.v15i2.26176.

Syaiful, Muhammad, Hasan Aedy, and Irmawatty Paula Tamburaka. "STRATEGI KOPERASI DALAM MENINGKATKAN KESEJAHTERAAN ANGGOTA." Jurnal Progres Ekonomi Pembangunan 1, no. 1 (2016). http://ojs.uho.ac.id/index.php/JPEP/article/view/874.

Tyas, Wido Prananing, Onixtin Octarina Sianturi, and Julius Kevin P H. "ANALISIS KEBIJAKAN PEMERINTAH DALAM PENGEMBANGAN USAHA MIKRO KECIL DAN MENENGAH (UMKM) BERBASIS RUMAH (HOME-BASED ENTERPRISES/HBE) DI KOTA SEMARANG, SURAKARTA, BOYOLALI, SALATIGA, DAN SURABAYA.” Jurnal Pengembangan Kota 8, no. 1 (July 1, 2020): 78-89. https://doi.org/10.14710/jpk.8.1.78-89.

Wibawa, Dian Prihardini, and Maya Yusnita. "Menakar Peran Pemerintah Dan Akademisi Terhadap Pengembangan UMKM." Jurnal Penelitian Ipteks. Vol. 5, January 14, 2020. https://doi.org/10.32528/IPTEKS.V5I1.3020.

\section{Internet}

https://www.republika.co.id/berita/ekonomi/keuangan/18/07/13/pbt6mp365-pemerintah-beripenghargaan-koperasi-berprestasi, accessed 17 September 2020

https://www.panjangport.co.id/?bW9kPXBhZ2UvYmVyaXRhJnBnPWRldGFpbF9iZXJpdGEmZGV0 YWlsPTU3JnJhbmRvbT01YlBqeThEQXQ= accessed 19 September 2020

http://www.mekarsai.org/detailpost/mekar-sai-raih-penghargaan-koperasi-berprestasi. $\quad$ accessed 19 September 2020

https://smartnews.id/kpri-handayani-dinobatkan-koperasi-berprestasi-tingkat-provinsi-lampung. accessed 19 September 2020

https://altumnews.com/2020/12/31/pemberdayaan-koperasi-dan-umkm-di-provinsi-lampung-ditengah-badai-covid-19/, accessed 11 March 2021 
